\title{
THE PATTERN OF THE ABO BLOOD GROUP FREQUENCIES IN IRELAND
}

\author{
W. E. R. HACKETT * \\ Late Medical Director, National Blood Transfusion Association of Ireland \\ G. W. P. DAWSON \\ School of Botany, Trinity College, Dublin \\ C. J. DAWSON \\ Chief Technician, National Blood Transfusion Centre, Dublin
}

Received 9.viii.55

THE genetic history of any population may be elucidated either by historical studies using written, oral and archæological evidence or by analysing the present day population to discover, if possible, the components of its composition. The two approaches are complementary and the primary aim of the present paper is to consider the frequencies of the $\mathrm{ABO}$ blood group genes in peoples in different parts of Ireland and to correlate these frequencies with what is known of the history of the population. As that which is new is the $A B O$ blood group survey, based on data collected in the course of the work of the National Blood Transfusion Association, this will be described at length and some account will also be given of the distribution of Rhesus-positive and Rhesus-negative people.

\section{AN OUTLINE OF THE HISTORY OF THE POPULATION OF IRELAND}

Ireland has no internal geographical barriers to speak of. The mountains are low, the rivers shallow. In general the most productive agricultural land is in the east, the most barren in the west, but there are few parts which are not inhabitable on a basis of either a tillage, a grazing or a fishing economy.

From archæological evidence it appears that Ireland was first inhabited in the immediate post-glacial period. Since these early mesolithic times the population has received successive additions by seaborne invasion. An inherent difficulty in interpreting archæological evidence in terms of the racial composition of the population is the fact that this evidence records customs and ways of life and changes in these may be due to their natural evolution, perhaps stimulated by contact with peoples overseas, to large-scale invasions, or to invasions by a small number of people who, because of their supremacy, in, say, the art of war, come to impose their traditions on the original inhabitants. The evidence of skeletal remains, while theoretically of greater value, is so scanty that he would be rash indeed who attempted to deduce from it the genetic history of prehistoric man in Ireland.

* Present address-School of Pathology, Trinity College, Dublin. 
Turning to historic times it would appear that from A.D. Ioo to A.D. 800 the country was ruled by a Gaelic aristocracy and it may be that this rule was over peoples of many distinct races. Prior to the Norse invasions of about 800 A.D. there was a unity of civilisation, law and language under a Gaelic High Kingship. Ireland was not conquered by the Romans.

The Norse invaders established colonies and fortresses round the coast and these were especially strong at Dublin, Wexford, Waterford, Cork and Limerick. For two hundred years they tried to subdue the country but their attempts ended when Brian Boru routed their Dublin garrison in I0I4. With the centre of their power destroyed the Norsemen's coastal settlements became isolated communities enjoying citizen rights under the High Kingship.

After a period of unsettled Gaelic rule, Ireland experienced a tide of Anglo-Norman invasion and settlement from i 66 to about I 300. This flow was mainly into south and east Louth, Meath, the eastern half of Westmeath, the eastern fringes of Offaly and Leix, Kildare, Dublin, Wicklow, Carlow, Wexford, Waterford, Kilkenny and Cork; and to a lesser degree into Limerick, south Tipperary and north Kerry. (Fig. I shows the county boundaries.) While much of the west was conquered it was never a settlement. area and was but sparsely garrisoned. In Ulster the area east of Lough Neagh was settled by $125^{\circ}$ but the area to the west, together with Roscommon and Leitrim never experienced much settlement. Donegal was never conquered and its resistance was, in part, due to help received from the galloglasses, mercenaries of mixed Gaelic and Norse descent from west Scotland. Many of these mercenaries settled in north-west Ireland, and during the fourteenth and fifteenth centuries groups of them offered their services to Irish lords and chiefs in many parts of the country. Neither the Anglo-Norman nor the later settlements penetrated the more mountainous regions of Ireland, such as are found in parts of Wicklow, Antrim and south-west Dublin.

In the fourteenth century there was an eastward movement of the Irish, at the expense of the Anglo-Normans, especially into Westmeath, Offaly, Leix, Limerick, north Kerry and the country regions of Cork. In Ulster the Anglo-Normans were pushed eastwards to the Ards.

By 1500 the King's writ ran only in Dublin, south Louth, Kildare and Meath, although some other districts were still effectively ruled by Anglo-Norman lords. This further contraction of the "pale" was as much due to Anglo-Normans being assimilated into the Irish community as to their replacement by the Irish. They were becoming Hibernis ipsis Hiberniores.

In the sixteenth century, under Mary, Leix and Offaly were planted with English but the numbers of these settlers were so small that their influence on the genetic composition of the population was probably insignificant. Under Elizabeth there were unsuccessful attempts to establish an English plantation in Munster and such slight 
English influences as there are to-day in the country regions of Cork probably date from this time.

The seventeenth century witnessed important changes in the composition of the population. Under "the articles of Plantation" of James I in I6og Ulster received numerous Scottish and English Protestants. While this plantation did not include the counties of Monaghan, Antrim and Down, the last two were soon assimilated by Scots who had settled in the Ards earlier in the century. These

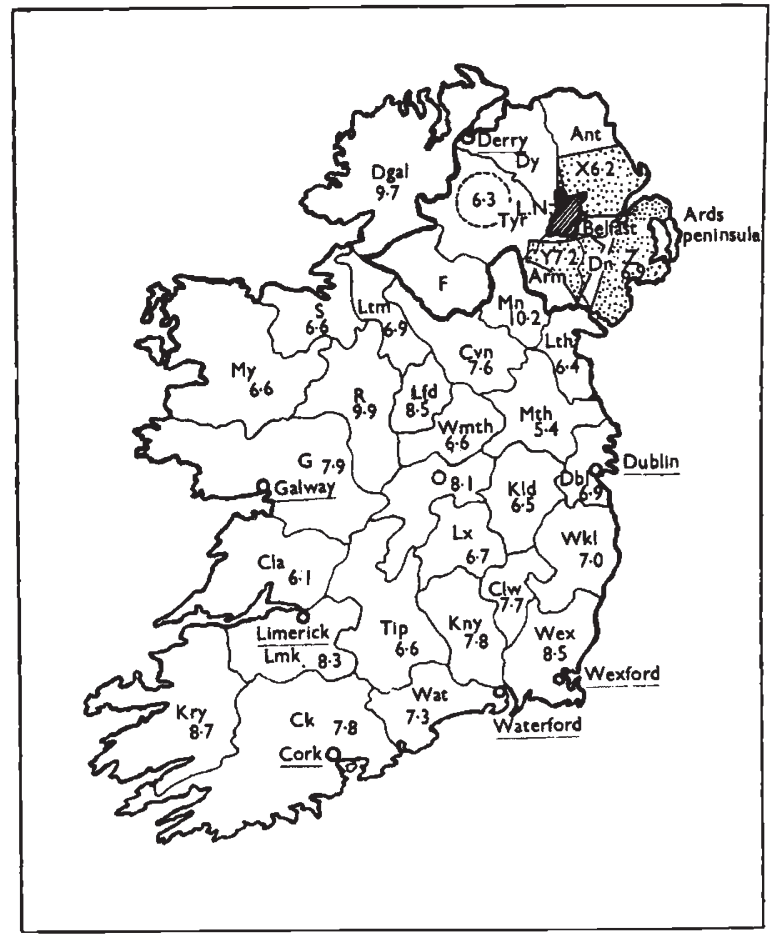

Fig. 1.-County boundaries and percentage frequency of group B gene. In this and subsequent figures the areas $\mathrm{X}, \mathrm{Y}, \mathrm{Z}$ are those of Hart's survey and show the gene frequencies calculated from his data. The present data for Northern Ireland are represented by a small circle.

Northern Ireland

Arm. Armagh

Ant. Antrim

Dy. Derry

Dn. Down

F. Fermanagh

Republic of Ireland

Cav. Cavan

Dgal. Donegal

Mn. Monaghan

Cla. Clare

Ck. Cork

Kry. Kerry

Lmk. Limerick

Tip. Tipperary

Wat. Waterford

L.N. Lough Neagh

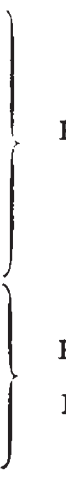

Province of

Munster

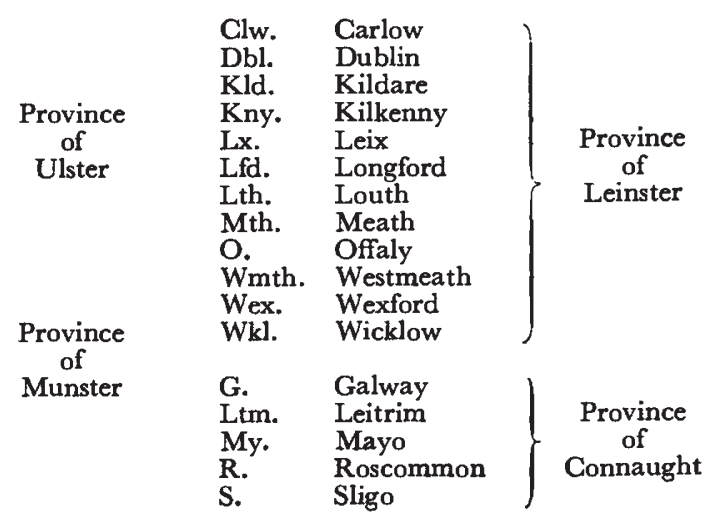


settlements were so successful that by ${ }^{1} 6_{4}$ I Protestants owned sixsevenths of the land of Ulster although they constituted numerically a smaller fraction of the total population. In the more southern parts of Ireland relatively unimportant settlements were established under James I in north Wexford, Longford, Leitrim, south Offaly and south Carlow and the adjoining part of Wicklow.

The Cromwellian settlements, partly reversed under Charles II, transplanted many land owners ("Irish Papists"-which included Anglo-Normans and English) and their retainers from many counties to Clare and Connaught with a corresponding influx of English into both town and country.

Apart from these additions the composition of the population in certain regions of Ireland may have been affected by racially selective losses due to emigration and other causes. Many thousands were lost by massacre, deportation and emigration during the seventeenth century. During the potato famine of $1846-48$ the population fell from 8 millions to about 6 millions and these losses were mainly from the poorer country regions.

Recent years have seen the growth of central government and industries in Dublin and the development of the county towns. This has resulted in migrations to these towns from the country.

\section{GENERAL CONSIDERATION OF BLOOD TRANSFUSION DATA}

The blood group data acquired by a transfusion service can be biassed in various ways. Appeals for blood may be made to particular population groups (say factory workers, or soldiers); there may be a conscious or unconscious selection of group $\mathrm{O}$ volunteers (" Universal Donors ") ; blood donation clinics may be set up only in the areas of densest population or greatest propinquity to the headquarters of the service-hence rural dwellers may be under-represented in the data of the area sampled. Resignations from the donor panels may not be at random, or lists of donors and their groups when "brought up-to-date" may exclude some original volunteers on a blood group basis. Depending on the laboratory techniques used, there may be a tendency to group certain $\mathrm{ABs}$ as $\mathrm{Bs}$, and there may be some bias towards a "safety-first" attitude in designating a doubtful blood to whatever category has least clinical danger. This is, however, more likely in Rh grouping where a doubtful Rh-negative is likely to become $\mathrm{Rh}$-positive in the blood bank so that it may not be given to an $\mathrm{Rh}$-negative recipient, while in ante-natal clinics the opposite tendency will be at work and a doubtful blood will be classed as Rh-negative because this is the safest practice from the mother's point-of-view.

\section{METHODS USED IN COLLECTING THE DATA}

When this survey began the National Blood Transfusion Association already had details of the blood groups of 10,000 newly-volunteered Irish donors. However, it was not certain that a small percentage of these did not already know their blood 
groups due to a wartime blood grouping campaign in certain towns, and because there might have been differential recruitment of group Os all this data was abandoned. The following scheme was then followed.

At donor sessions all new donors (i.e. those who had never given blood before and were now giving a full donation for the first time) were asked whether they knew their blood group. If they did not the following information was recorded : 1. Mr, Miss or Mrs. 2. Surname. 3. Christian name. 4. Present address. 5 . Occupation. 6. Birthplace in Ireland. After their blood had been to the central laboratory of the Transfusion Service, there was added 7. ABO group and $8 . \mathrm{Rh}$ group (D group only). In the records department this information was typed on a card of one of four colours according to the ABO group. This "survey card" was different from the one used for the master card index in the central record of the donor panel, and so could be removed from the records office without causing confusion. The master card was also coloured according to the $\mathrm{ABO}$ group and as the survey card was typed by the same typist at the same time there was little chance of error.

The survey cards were then sorted by county of birthplace. "Birthplace" was chosen in preference to "present residence" for the following reasons : I. It move; the geographical location of the blood groups backwards in time by twenty to forty years. This will tend to reduce the blurring effect of the considerable countryto-town population movements of the last thirty years. 2. It gives a country-wide cover in a short time because many Irish blood donors live or work in different cities, towns or counties from those in which they were born. As there are many counties in which the National Blood Transfusion Service does not hold donor clinics because of either distance, thinness of population, or the fact that local blood transfusion schemes are already in operation, a survey based on "present residence" would mean special expeditions to particular counties or else would involve reliance on second-hand data from sources where the laboratory methods or the bias in collecting could not be fully checked.

\section{LABORATORY METHODS}

High titre selected grouping sera, stored at $-20^{\circ} \mathrm{C}$., were used. Particular care was taken to make sure that the anti-A gave strong agglutination with $A_{2}$ and $\mathrm{A}_{2} \mathrm{~B}$ bloods. All grouping was done in test tubes and usually in batches of 60 to 120 bloods. Cells and serum were grouped; a different technician reading the agglutinogen and the agglutinin content. Every batch of grouping was controlled with known cells and serum. Any blood showing a discrepancy at first reading between cells and serum was re-grouped. Any batch of groupings showing more than 5 discrepancies in oo between agglutinogens and agglutinins at first reading was repeated in toto. (Such occasions were very rare, being usually due either to agglutinins acting as hæmolysins in warm weather, or to attempting to read the results too quickly on days when the work was rushed.)

Such findings as cold auto-agglutination, rouleaux formation, $\mathrm{AB} \alpha$ and $\mathrm{A} \alpha \beta$ were fully investigated until the correct interpretation or subgroup was assigned $\left(\mathrm{A}_{2} \mathrm{~B} \alpha_{1}, \mathrm{~A}_{2} \alpha_{1} \beta\right.$, etc.). All $\mathrm{O} \alpha \beta$ bloods were rechecked with pooled group $\mathrm{O}(\alpha \beta)$ serum to eliminate the possibility of weak As being missed by the anti-A in the original test. Such bloods were very rare indeed. The recorded results were checked twice to avoid clerical errors.

$\mathrm{Rh}$ grouping was by saline anti-D serum incubated for one hour at $37^{\circ} \mathrm{C}$. and read by observing the pattern on the bottom of the tube with a hand lens. All bloods showing " Rh-negative" on this first reading were re-grouped using a different sample of saline anti-D.

\section{THE BLOOD GROUP DATA}

The ABO and Rh blood group data for men and women in each of the twenty-six counties of the Republic is given in the appendix. 
As only a small number of these donors were born in Northern Ireland our data for these counties has been summed and entered under the heading "Six Counties".

\section{THE ANALYSIS OF THE ABO BLOOD GROUP DATA}

The reasonableness of the county samples was tested by the usual method of comparing the observed with the expected number of

TABLE I

\begin{tabular}{|c|c|c|c|c|c|c|c|c|c|}
\hline \multirow{2}{*}{ County } & & & \multirow{2}{*}{$\begin{array}{l}\text { Total } \\
\text { number } \\
\text { of donors }\end{array}$} & \multirow{2}{*}{$\begin{array}{c}\text { Observed } \\
\text { AB }\end{array}$} & \multirow{2}{*}{$\begin{array}{c}\text { Expected } \\
\mathrm{AB}\end{array}$} & \multirow{2}{*}{$x^{2}$} & \multicolumn{3}{|c|}{ Gene frequencies } \\
\hline & & & & & & & $\mathrm{O}$ & $\mathbf{A}$ & B \\
\hline Carlow. & . & . & 688 & 21 & $22 \cdot 25$ & 0.05 & 0.714 & 0.209 & 0.077 \\
\hline Cavan. & . & . & 944 & 26 & $25 \cdot 23$ & 0.02 & 0.747 & 0.177 & 0.076 \\
\hline Clare & . & . & 187 & 4 & 3.01 & $\ldots$ & 0.807 & 0.132 & 0.061 \\
\hline Cork & . & - & 533 & 10 & $12 \cdot 22$ & 0.32 & 0.776 & $0 \cdot 146$ & 0.078 \\
\hline Donegal & - & - & 142 & I & $5 \cdot 01$ & $2 \cdot 39$ & 0.726 & 0.177 & 0.097 \\
\hline Dublin. & . & . & 8,182 & 253 & $228 \cdot 09$ & $2 \cdot 02$ & 0.729 & $0.20 \mathrm{I}$ & 0.069 \\
\hline Galway . & • & . & $76_{5}$ & 17 & r8.95 & $0 \cdot 16$ & 0.764 & $0 \cdot 157$ & 0.079 \\
\hline Kerry . & . & . & 258 & 3 & 5.63 & 0.97 & $0 \cdot 769$ & $0 \cdot 144$ & 0.087 \\
\hline Kildare . & & & 581 & 15 & $14 \cdot 88$ & 0.00 & $0.73^{8}$ & O.198 & 0.065 \\
\hline Kilkenny & . & . & 931 & 27 & $29 \cdot 21$ & $0 \cdot 12$ & 0.722 & $0 \cdot 200$ & 0.078 \\
\hline Leitrim . & - & - & 113 & 7 & $2 \cdot 43$ & $\ldots$ & 0.768 & 0.163 & 0.069 \\
\hline Leix & . & - & 674 & 17 & $14 \cdot 76$ & 0.27 & $0 \cdot 769$ & $0 \cdot 164$ & 0.067 \\
\hline Limerick & . & . & $27 i$ & 5 & $8 \cdot 54$ & $I \cdot 09$ & 0.729 & $0 \cdot 188$ & 0.083 \\
\hline Longford & & . & $23^{6}$ & 8 & 5.95 & 0.55 & $0 \cdot 765$ & 0.150 & 0.085 \\
\hline Louth & & . & 1,650 & 31 & $39 \cdot 58$ & $I \cdot 4^{2}$ & 0.750 & 0.186 & 0.064 \\
\hline Mayo & & & 426 & 9 & $8 \cdot 29$ & 0.05 & $0 \cdot 786$ & $0 \cdot 14^{8}$ & $0.06 \hat{6}$ \\
\hline Meath. & & & 241 & 2 & $5 \cdot 47$ & $x \cdot 65$ & $0 \cdot 73^{8}$ & 0.209 & 0.054 \\
\hline Monaghan & & & I6o & 3 & $5 \cdot 50$ & $0 \cdot 86$ & 0.743 & 0.155 & 0.102 \\
\hline Offaly . & & - & I 56 & 5 & $5 \cdot 41$ & 0.02 & 0.706 & 0.212 & 0.081 \\
\hline Roscommon & . & • & $55^{2}$ & 15 & $19 \cdot 27$ & $0 \cdot 70$ & $0 \cdot 726$ & $0 \cdot 176$ & 0.099 \\
\hline Sligo & . & - & I 57 & 6 & $3 \cdot 77$ & ... & 0.750 & 0.184 & 0.066 \\
\hline Tipperary & . & . & 421 & II & $10 \cdot 12$ & 0.06 & 0.754 & 0.179 & 0.066 \\
\hline Waterford & & & 1,209 & 44 & $34 \cdot 24$ & $2 \cdot 07$ & $0.73 i$ & $0 \cdot 196$ & 0.073 \\
\hline Westmeath & & & 447 & 9 & $9 \cdot 12$ & 0.00 & 0.763 & 0.171 & 0.066 \\
\hline Wexford & & & 438 & II & I $6 \cdot 99$ & $I \cdot 49$ & 0.689 & 0.226 & 0.085 \\
\hline Wicklow & & . & 1,037 & 27 & $30 \cdot 95$ & 0.37 & 0.717 & 0.213 & 0.070 \\
\hline Six Counties & & - & 495 & 5 & I I 89 & $3 \cdot 03$ & $0 \cdot 74^{8}$ & $0 \cdot 189$ & 0.063 \\
\hline Total data & & - & $2 x, 894$ & 592 & $587 \cdot 4^{8}$ & 0.03 & $0.73^{8}$ & 0.190 & $0.07^{2}$ \\
\hline
\end{tabular}

ABs. For these calculations the numbers of men and women, Rhpositive and $R h$-negative, were added together. The resulting values of $\chi^{2}$ and the frequencies of the $\mathrm{O}, \mathrm{A}$ and $\mathrm{B}$ genes are presented in table $\mathrm{I}$.

The good agreement between the observed and expected numbers of $A B s$ suggests that the county data can be assumed to be good random samples. An interesting feature of this data is that, whereas all previously published data for Dublin showed a deficiency of $A B$ donors (Dawson, 1952), the present Dublin data shows good agreement between the expected and observed numbers. This may perhaps be taken as an indication that there was a slight, but significant, bias in the previous data which has not appeared in the present survey due to the greater care that has been taken to ensure random sampling. 
The variation in the distribution of group $B$ was investigated by calculating the heterogeneity $\chi^{2}$ for the relative numbers of $\mathrm{O}+\mathrm{A}$ and $B+A B$ donors in the various counties. As its value is 34.98 for 26 degrees of freedom $(P=0 \cdot I)$ no significant heterogeneity is established. The county frequencies of gene $\mathrm{B}$ are plotted in fig. I. There is no evidence of any area of Ireland having a significantly higher B gene frequency than any other area-the counties appear to be randomly distributed with respect to their B gene frequencies. (Gene frequencies calculated from Hart's survey of blood groups in

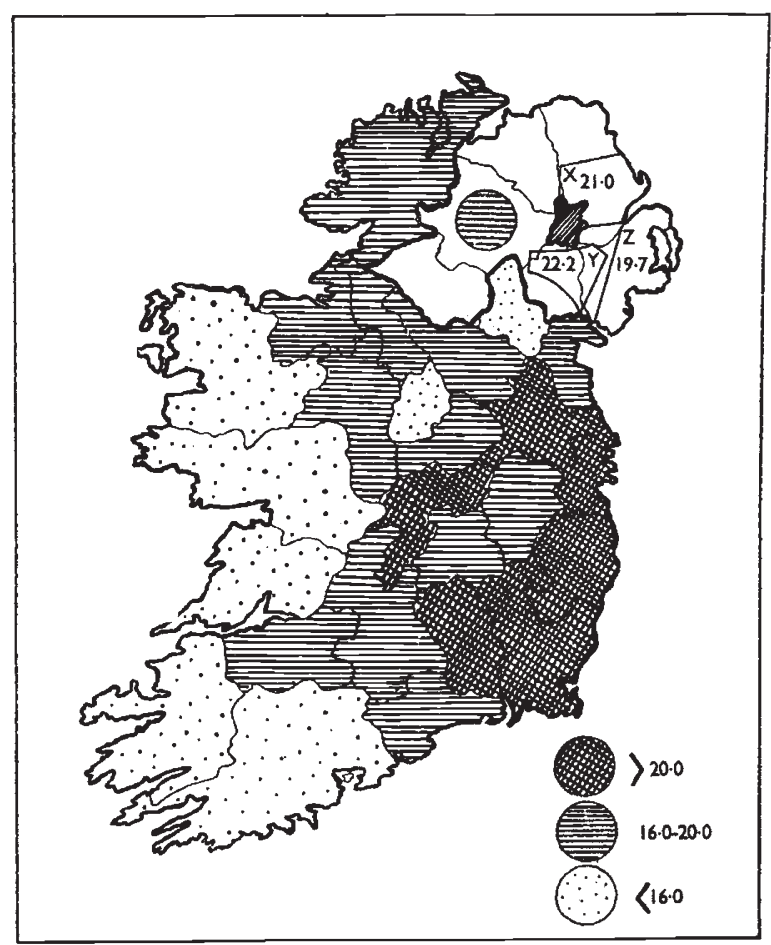

FIg. 2.-Percentage frequency of group A genc.

certain areas of Northern Ireland (Hart, 1944) are included in this map and in figs. 2 and 3. Hart's data was sorted according to "present residence" of donors.)

The calculation of the heterogeneity $\chi^{2}$ for the relative numbers of $\mathrm{A}+\mathrm{AB}$ and $\mathrm{O}+\mathrm{B}$ donors will give an indication of the significance or otherwise of the variations from county to county of the frequency of group A. The $\chi^{2}$ has a value of $100 \cdot 8 \mathrm{I}$ for 26 degrees of freedom which leaves no room to doubt the significance of the heterogeneity in the distribution of group A. As the frequency of group B is so small and shows no significant heterogeneity in its distribution, the variation in group $\mathrm{A}$ is to be interpreted as variation in the relative frequencies of genes $\mathrm{A}$ and $\mathrm{O}$. These frequencies are plotted in 


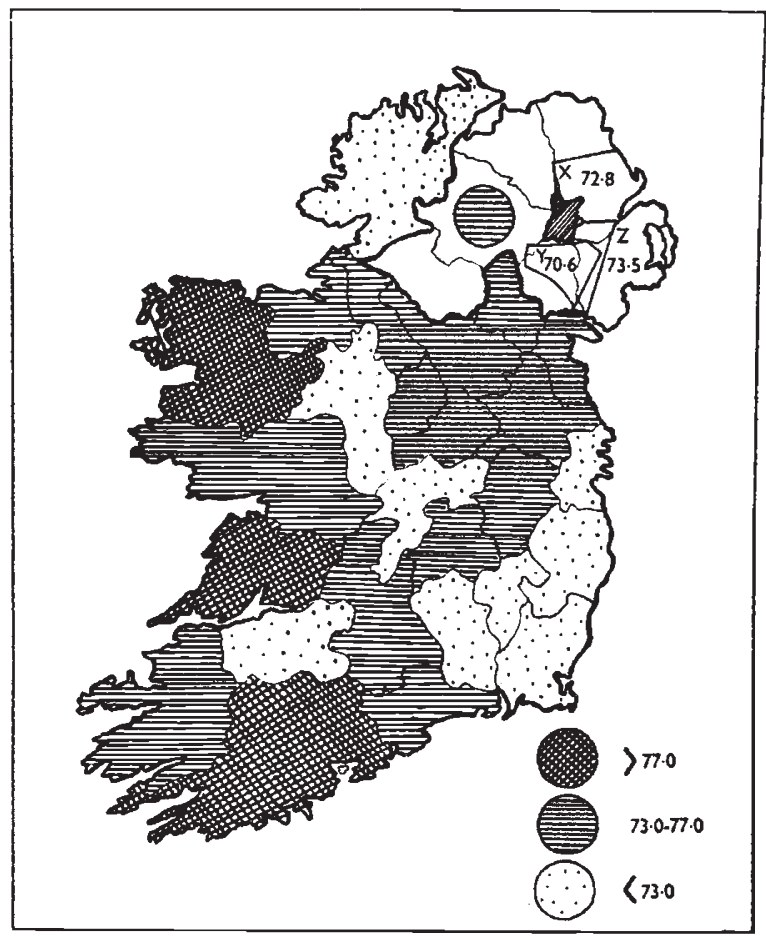

Fic. 3--Percentage frequency of group $\mathrm{O}$ gene.

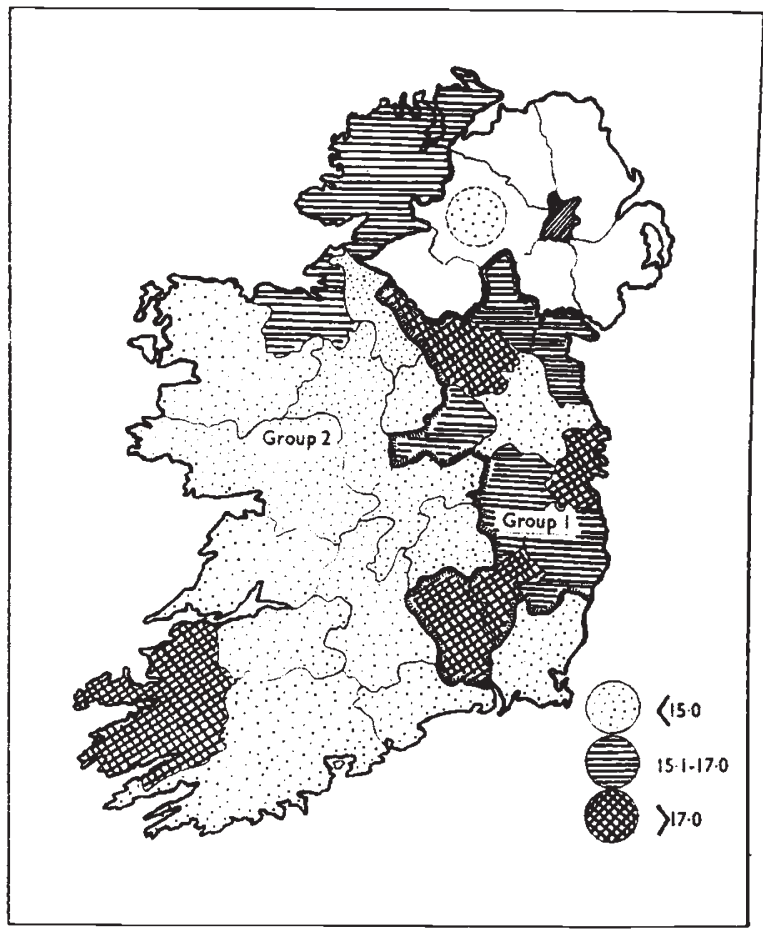

Fig. 4--Percentage frequency of Rhesus-negative donors. 
figs. 2 and 3. These maps clearly reveal an important difference between the eastern and western counties in that the counties in the west have higher $\mathrm{O}$ and lower $\mathrm{A}$ gene frequencies than those in the east. The frequencies are intermediate in the central counties. The general pattern is so clear that it would appear to be unnecessary to establish it by further statistical analysis.

\section{THE ANALYSIS OF THE RHESUS BLOOD GROUP DATA}

The analysis of the relative numbers of $\mathrm{Rh}$-positive ( $\mathrm{D}$-positive) and Rh-negative (D-negative) donors (all ABO groups, men and women, summed) reveals significant heterogeneity between counties. The heterogeneity $\chi^{2}$ for 26 degrees of freedom is $44.01, P=0.02$. The frequency of Rh-negative donors in each county is shown in fig. 4, and it is apparent that almost all the counties with a high frequency form a block in the central region of the eastern half of the country. This block of counties is called Group $\mathrm{I}$ and includes Carlow, Cavan, Dublin, Kildare, Kilkenny, Louth, Meath, Monaghan, Westmeath and Wicklow. Group 2 includes all the other counties. This division separates those counties with a proportion of $\mathrm{Rh}$-negative donors greater than 0.155 (Group I) from those with a proportion less than O.I55 (Group 2); the only exceptions being Meath (0. I49) in Group I and Sligo (0.166) and Kerry (0.182) in Group 2. These three exceptions fall into that third of the counties for which one has the fewest observations.

When an area is subdivided by direct inspection of the blood group frequencies, precise statistical analysis of the heterogeneity of these frequencies between and within the subdivisions is logically hazardous. However, once heterogeneity is established in the data, it is justifiable to attempt to interpret this in terms of a spatial pattern of blood group frequencies. From the present data we can probably go no further than saying that it appears that in the central eastern counties of Ireland (Group I) there is a significantly higher frequency of Rh-negative donors than in the other counties.

The Rh-positive and Rh-negative frequencies in the total data of 21,894 donors from all counties are 0.8387 and 0.1613 respectively.

The frequencies of $\mathrm{Rh}$-positives and $\mathrm{Rh}$-negatives in the 8,182 donors born in Dublin are 0.8293 and 0.1707 . These agree well with the previously published frequencies of 0.8376 and 0.1624 based on 4,058 women resident in Dublin (Stewart, 1947) $\chi^{2}=\mathrm{I} \cdot 35$, $\mathrm{P}=0.25$.

\section{THE RELATIONSHIPS BETWEEN SEX, ABO AND RHESUS (Dd) BLOOD GROUPS}

The relationship between sex and $\mathrm{Rh}$-positive and $\mathrm{Rh}$-negative grouping was investigated by a $2 \times 2$ contingency table for the total data. The $\chi^{2}$ obtained is $\mathrm{I} \cdot 02$, I degree of freedom, $\mathrm{P}=0 \cdot 3$. Thus there is no significant association between sex and $\mathrm{Rh}$ group. 
The corresponding value of $\chi^{2}$ for the relation between the $\mathrm{Rh}$ and $A B O$ groups is $5 \cdot 10,2$ degrees of freedom, $P=0.08$. In this analysis the numbers of donors of groups $B$ and $A B$ were added, thus giving a $3 \times 2$ contingency table for the total data. The correlation between these blood groups is doubtfully significant and it is interesting to notice that what association there is can be wholly attributed to the data for Dublin, where group A contains a lower proportion of $\mathrm{Rh}$-negative than do the other groups (table 2 ). The $3 \times 2$ contingency table for this Dublin data gives a $\chi^{2}$ of $12 \cdot 24,2$ degrees of freedom, $\mathrm{P}=0.004$.

The Dublin data is consistent with that for the rest of the country in showing good agreement between the expected and the observed numbers of $\mathrm{AB}$ donors and in the absence of any associations between the $A B O$ blood groups and sex and between the $R h$ grouping and

TABLE 2

Proportions of $O, A$ and $B+A B$ donors that are Rh-negative

\begin{tabular}{|c|c|c|c|c|}
\hline & & Dublin & Total data & $\begin{array}{c}\text { Total data } \\
\text { excluding Dublin }\end{array}$ \\
\hline O. & . $\quad$. & $0 \cdot 1822$ & $0 \cdot 1648$ & $0 \cdot 1549$ \\
\hline A. & . & $0 \cdot 1503$ & 0.1541 & $0 \cdot 1565$ \\
\hline $\mathrm{B}+\mathrm{AB}$ & . & $0 \cdot 1762$ & 0.1640 & $0 \cdot 1569$ \\
\hline
\end{tabular}

sex. It may be that this abnormal association of Rh-positive and group $\mathrm{A}$ is a rare chance error. Whether this is so, or not, will be decided by collecting more data for Dublin.

The analysis of the proportions of $\mathrm{O}, \mathrm{A}$ and $\mathrm{B}+\mathrm{AB}$ donors among men and women in the total data gives a $\chi^{2}$ of $3.03,2$ degrees of freedom, $P=0 \cdot 2$. Thus there appears to be no significant association between sex and the $\mathrm{ABO}$ groups.

From the published data from many countries it appears that it is exceptional to find any associations between sex, $\mathrm{Rh}$ and $\mathrm{ABO}$ blood groups. The absence of significant correlations in the present survey may thus be taken to confirm, in a general way, the validity of the methods that were used for collecting the data.

\section{DISCUSSION}

For Europe the broad pattern of $\mathrm{ABO}$ blood group frequencies is now well known. The main western peoples have a high group $\mathrm{A}$ frequency while the frequency of the much rarer group $B$ is highest among the Slavs and other eastern Europeans.

The highest group $\mathrm{O}$ incidence is in the peripheral north-westIceland, Scotland, Ireland and parts of Wales. There are other 
peoples living on the southern edge of the continent, in Sardinia, Crete and the western Caucasus, who, together with the Berbers of North Africa, have also high group $\mathrm{O}$ frequencies.

The frequency of the $\mathrm{Rh}$ groups shows little variation as far as $\mathrm{D}$ grouping is concerned, but a notable exception to this is found in the Basque people who have a very high proportion of $\mathrm{D}$ negatives, along with much group $\mathrm{O}$ and very little group $\mathrm{B}$.

Within the British Isles group $\mathrm{A}$ is common in the south of England (the gene frequency is between 0.25 and 0.30 ) but the $\mathrm{A}: \mathrm{O}$ ratio decreases as one travels north into Scotland. In the Highlands of Scotland, a region in which there are strong Norse and Celtic elements, the A gene frequency falls to below 0.20. The $\mathrm{ABO}$ frequencies in Wales have been shown by Mourant and Watkin (1952) to contain remarkable local divergences. There is a high group $\mathrm{O}$ area (gene frequency of over 0.75 ) in North Wales, high group B (over $0^{\cdot 15}$ ) in a small area in Carmarthenshire, and a high group A area (over 0.30 ) in the south of the Principality.

Against this general pattern of blood group frequencies in Europe we can consider the interpretation of the results of the present survey of Ireland.

In Ulster the effect of the vast English and Scottish plantations under James I is clearly reflected in the relatively high A gene frequency. In a comparative analysis of the blood group frequencies of people with English, Scottish and Irish surnames in Northern Ireland (Hart, 1944) it was shown that while the frequencies among Scottish and Irish were similar those among English tended to match the frequencies found in England. Thus the relatively high A gene frequency in the north is probably to be attributed primarily to English settlers. It is interesting to note that the A gene frequency found in the present small sample from Northern Ireland is somewhat lower than the frequencies found by Hart. This is probably due to the fact that the present survey includes only those born in the Six Counties and now resident in the south-they would be expected to be drawn primarily from among those who had connections with southern Ireland, where lower A gene frequencies are found.

In the three southern provinces of Ireland the most striking feature of the county pattern of the $\mathrm{ABO}$ blood groups is the highly significant difference in the $\mathrm{O}$ and $\mathrm{A}$ gene frequencies between the eastern and western counties. This difference was first shown by Hooper (1947). The $\mathrm{O}$ gene occurs with highest frequency $(0.76$ to 0.81$)$ and the A gene with lowest (0.13 to 0.16$)$ in the western counties of Mayo, Galway, Clare, Kerry and Cork. The eastern counties with $\mathrm{O}$ gene frequencies between 0.69 and 0.74 and $\mathrm{A}$ gene frequencies between 0. I9 and 0.23 approximate closest to the frequencies found in England. In a large sample drawn from many parts of the United Kingdom the $\mathrm{O}$ and $\mathrm{A}$ gene frequencies were 0.68 and 0.26 (Dobson and Ikin, 1946). These regions rich in A genes correspond almost exactly with 
the areas of most intensive Anglo-Norman settlement, later supplemented by settlements under Cromwell and to a much lesser degree under James I.

It is, however, interesting that the A gene frequency in the eastern counties is as high as it is. While admitting the unreliability of deducing gene frequencies in past populations from present-day gene frequencies, we may tentatively accept Dobson and Ikin's frequency of the $\mathrm{O}$ gene as being roughly its frequency among those coming to Ireland from England in historical times. If the original population of the whole of Ireland had an $\mathrm{O}$ gene frequency similar to that now found in the west $(0.77)$ we should have to conclude that the present population of the eastern counties (0.73) was a mixture of AngloNorman and later settlers with original inhabitants in about the ratio of 4 to 5 . This is in reasonable accord with much historical evidence, and in particular with the fact that, following the Anglo-Norman incursions, large numbers of merchants and farmers from England settled in the eastern counties of Ireland.

The influence of the Norse settlements appears to be masked by the east-west gradient with the possible exception of Limerick, where the relatively high A gene frequency may be due to a Norse component in the population.

If this historical interpretation is valid we must conclude that the present pattern of $\mathrm{A}, \mathrm{B}$ and $\mathrm{O}$ gene frequencies in Ireland is primarily the result of invasions, incursions and settlements that have occurred during the last 1200 years.

The pattern of the $\mathrm{A}$ and $\mathrm{O}$ gene frequencies is also apparent in much anthropometric data for Ireland. For comparison some of this data is reproduced from maps in Coon's The Races of Europe, as fig. 5. For all these measurements those of the east of Ireland are more close to those of England than are those of the west. It is also significant that those regions of Ireland where Irish is most widely spoken are situated in the zone of highest $\mathrm{O}$ gene frequency.

The present data amply confirms the generally accepted picture of a slightly but significantly higher B gene frequency in the extreme west of Europe than in those areas immediately adjoining. The data of Dobson and Ikin (1946) for the United Kingdom showed a frequency of 0.060 , that of Fraser Roberts (1953) for the north of England 0.062 while the present data gives an average frequency of 0.072 for the whole of Ireland.

The present slight variation in the distribution of the Rhesus (D) blood groups may reflect a prehistoric pattern.

In a study comparing the distribution of the $\mathrm{TH}$ sound among the languages and dialects of the peoples of Europe with the distribution of the frequency of the $O$ gene, Darlington (1947) stated that the Celtic languages contain the $\mathrm{TH}$ sound. While this may have been true in the distant past, modern Irish possesses the dental plosive and not the fricative. The only exceptional region is south-west 
Ireland where the alveolar plosive is found and Darlington, noting the absence of the TH sound from this region, suggested that it and Portugal (a non-TH area) may represent relic regions of a Megalithic people. However, it now appears impossible to link these regions together as Portugal has one of the lowest $\mathrm{O}$ gene frequencies in western Europe $(0.60)$ while the frequency in south-west Ireland is higher than in any other region of Europe (0.77).

In general it may be said that the gradient of blood group gene frequencies found in Ireland and the absence of obvious pockets of

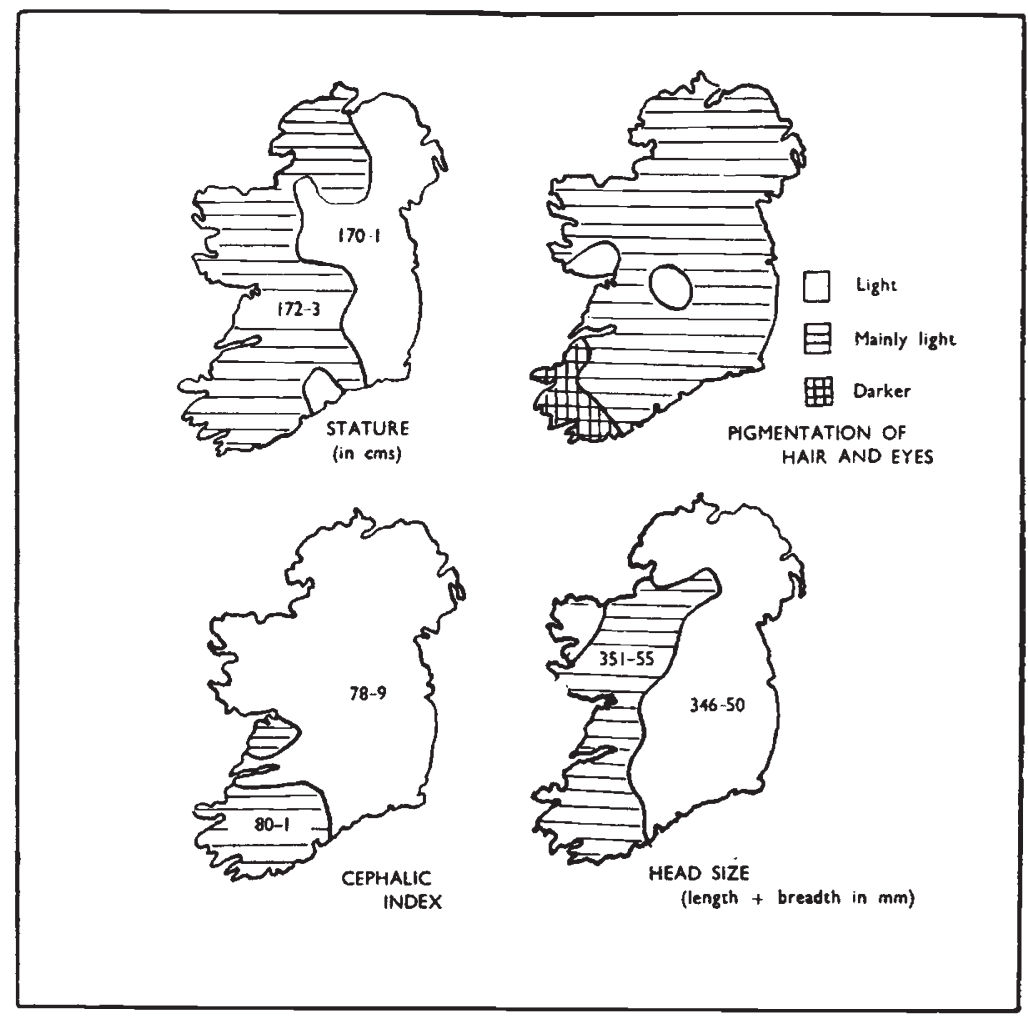

FIG. 5.-The distribution of physical characteristics.

(Taken from maps in Coon's The Races of Europe.)

exceptional frequencies reflect the absence of geographical barriers to population movements within the country. In this the type of gene frequency pattern is similar to that of England and in marked contrast to that of Wales.

The present data confirms the similarity in $\mathrm{O}$ gene frequencies between western Ireland and Iceland, where its frequency is 0.75 . This suggests a closer genetic relationship between the populations of these two areas than between Iceland and modern Scandinavia, which, in spite of cultural affinities, have widely different $O$ gene frequencies. 


\section{SUMMARY}

I. Records of 21,894 blood donors in Ireland were sorted according to the counties in which the donors were born. The analysis of the $\mathrm{ABO}$ gene frequencies has shown that while the $\mathrm{B}$ frequency is higher than in England and varies little, there is significant reciprocal variation in the frequencies of the $\mathrm{O}$ and $\mathrm{A}$ genes. The average frequency of the $\mathrm{O}$ gene in those counties in the west and south-west is 0.77 while in the eastern counties the frequency is only slightly greater than $0 \cdot 70$.

2. In the three southern provinces the regions of highest A gene frequency correspond to those regions which have received most settlers from England-Anglo-Norman and Cromwellian settlements being the most important. In Ulster the high A gene frequency is primarily attributed to the English who entered the area under the scheme of plantation of James $\mathrm{I}$. The distribution of the $\mathrm{O}$ and $\mathrm{A}$ gene frequencies is thus interpreted in terms of additions to the population of Ireland during the last 1200 years.

3. The patterns of various anthropological measurements are in general agreement with the patterns of $\mathrm{O}$ and $\mathrm{A}$ gene frequencies.

4. Doubtfully significant heterogeneity between counties in the frequency of Rh-positive donors is recorded. There may be a block of counties in the central eastern part of the country which has a higher percentage of Rh-negatives than elsewhere.

Acknowledgments.-We wish to acknowledge gratefully the assistance we have received from the Board and Medical Director of the National Blood Transfusion Association of Ireland. Only with their co-operation would this survey have been possible.

We also wish to express our thanks to the staff of the blood transfusion service for collecting and recording the data and to the many medical students who helped to sort and count it.

To Professor J. Otway-Ruthven we are deeply indebted for guiding us through the complexities of Irish history and to Mr E. G. Quin for information on Irish philology.

We wish to thank Dr Fraser Roberts, Dr Mourant and Professor Darlington for their help in preparing this account for the press.

\section{REFERENCES}

coon, c. s. 1948. The Races of Europe. New York.

DARLINGTON, C. D. 1947. The genetic component of language. Heredity, $1,269-286$. DAwson, G. W. P. 1952. The frequency of the ABO blood groups in Dublin. Heredity, 6, 243-246.

DOBSON, A. M., AND IKIN, E. W. I946. The ABO blood groups in the United Kingdom; frequencies based on a very large sample. 7. Path. Bact., $5^{8}$, $221-227$.

HART, E. W. 1944. An analysis of the blood group composition of a population in Northern Ireland. Ann. Eugen., 12, 89-Ior.

HOOPER, I. 1947. Blood group distributions in Ireland. Irish 7. Med. Sci., 259, $47 \mathrm{I}-479$.

MOURANT, A. E., AND WATKIN, I. M. 1952. Blood groups, anthropology and language in Wales and the western counties. Heredity, 6, 1 3-36.

STEWART, F. S. I947. Report on the investigation of Rh immunisation. Report of the Rotunda Hospital, Dublin, I946-1947. 


\section{APPENDIX}

TABLE I

Total data (Men)

\begin{tabular}{|c|c|c|c|c|c|c|c|c|c|c|}
\hline \multirow{2}{*}{ County } & & \multicolumn{2}{|c|}{$\mathrm{O}$} & \multicolumn{2}{|c|}{ A } & \multicolumn{2}{|c|}{ B } & \multicolumn{2}{|c|}{$\mathrm{AB}$} & \multirow{2}{*}{ Totals } \\
\hline & & $\mathrm{Rh}+$ & $\mathrm{Rh}-$ & $\mathbf{R h}+$ & $\mathrm{Rh}-$ & $\mathrm{Rh}+$ & $\mathbf{R h}-$ & $\mathrm{Rh}+$ & $\mathrm{Rh}-$ & \\
\hline Carlow & . & 212 & 42 & 120 & 39 & 44 & 14 & 12 & 5 & 488 \\
\hline Cavan & . & 356 & 69 & 167 & 53 & 82 & 15 & II & 6 & 759 \\
\hline Clare . & . & 81 & 12 & 28 & 3 & 13 & $\mathrm{I}$ & 3 & 0 & $I 4^{I}$ \\
\hline Cork & . & 218 & 38 & $8 \mathrm{r}$ & 14 & 52 & 3 & 9 & I & $4^{16} 6$ \\
\hline Donegal & . & $5^{6}$ & 7 & 26 & 10 & 17 & 2 & $I$ & 0 & 119 \\
\hline Dublin & . & 2395 & 537 & I 568 & 274 & 473 & 100 & ${ }^{1} 5^{1}$ & 29 & 5527 \\
\hline Galway & . & 296 & 44 & 143 & 23 & 59 & 8 & 12 & 2 & 587 \\
\hline Kerry & $\cdot$ & 99 & 20 & 39 & II & 19 & 3 & 2 & I & 194 \\
\hline Kildare & 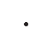 & 218 & 55 & 135 & 22 & 47 & 4 & 10 & 2 & 493 \\
\hline Kilkenny & . & 305 & 69 & 189 & 37 & 68 & II & 24 & o & 703 \\
\hline Leitrim & 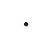 & 44 & 4 & 19 & 1 & 9 & 2 & 6 & I & 86 \\
\hline Leix & & 269 & $4^{2}$ & 128 & 15 & 50 & 10 & 6 & 3 & 523 \\
\hline Limerick & . & 106 & 77 & 53 & $Y_{I}$ & 22 & 3 & 4 & o & 216 \\
\hline Longford & . & 95 & II & $3^{8}$ & 7 & 23 & 3 & 6 & o & 183 \\
\hline Louth & . & 605 & 129 & 325 & $5^{6}$ & 96 & 23 & 18 & 3 & 1255 \\
\hline Mayo & . & 160 & 24 & 66 & 10 & 22 & 8 & 7 & o & 297 \\
\hline Meath & . & 90 & 17 & 64 & 9 & 17 & 2 & I & I & $20 I$ \\
\hline Monaghan . & 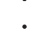 & 56 & Io & 30 & 6 & 15 & 2 & 2 & I & 122 \\
\hline Offaly & . & 54 & 8 & 42 & 6 & 16 & 2 & 3 & 2 & 133 \\
\hline Roscommon & . & I 71 & 30 & 100 & 17 & 50 & 9 & 6 & 3 & 386 \\
\hline Sligo & . & 49 & 12 & 29 & 6 & II & 2 & 2 & I & 112 \\
\hline Tipperary & & 161 & 27 & $9^{6}$ & 10 & 30 & 7 & 6 & 2 & 339 \\
\hline Waterford. & . & 427 & 77 & 261 & 32 & 91 & 12 & 33 & 5 & 938 \\
\hline Westmeath . & . & 164 & 35 & 93 & 12 & 23 & Io & 7 & 0 & 344 \\
\hline Wexford & 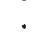 & 157 & 27 & 107 & 18 & 42 & 5 & 9 & I & 366 \\
\hline Wicklow & . & 304 & 55 & 218 & 50 & 69 & 6 & 9 & 4 & 715 \\
\hline Six Counties & & 213 & 30 & 112 & 21 & 34 & 5 & 3 & 0 & $41^{8}$ \\
\hline Totals & . & $736 \mathrm{x}$ & \begin{tabular}{|l|}
1448 \\
\end{tabular} & 4277 & 773 & 1494 & 272 & $3^{6} 3$ & 73 & $16,06 x$ \\
\hline
\end{tabular}


84 W. E. R. HAGKETT, G. W. P. DAWSON AND G. J. DAWSON

TABLE 2

Total data (Women)

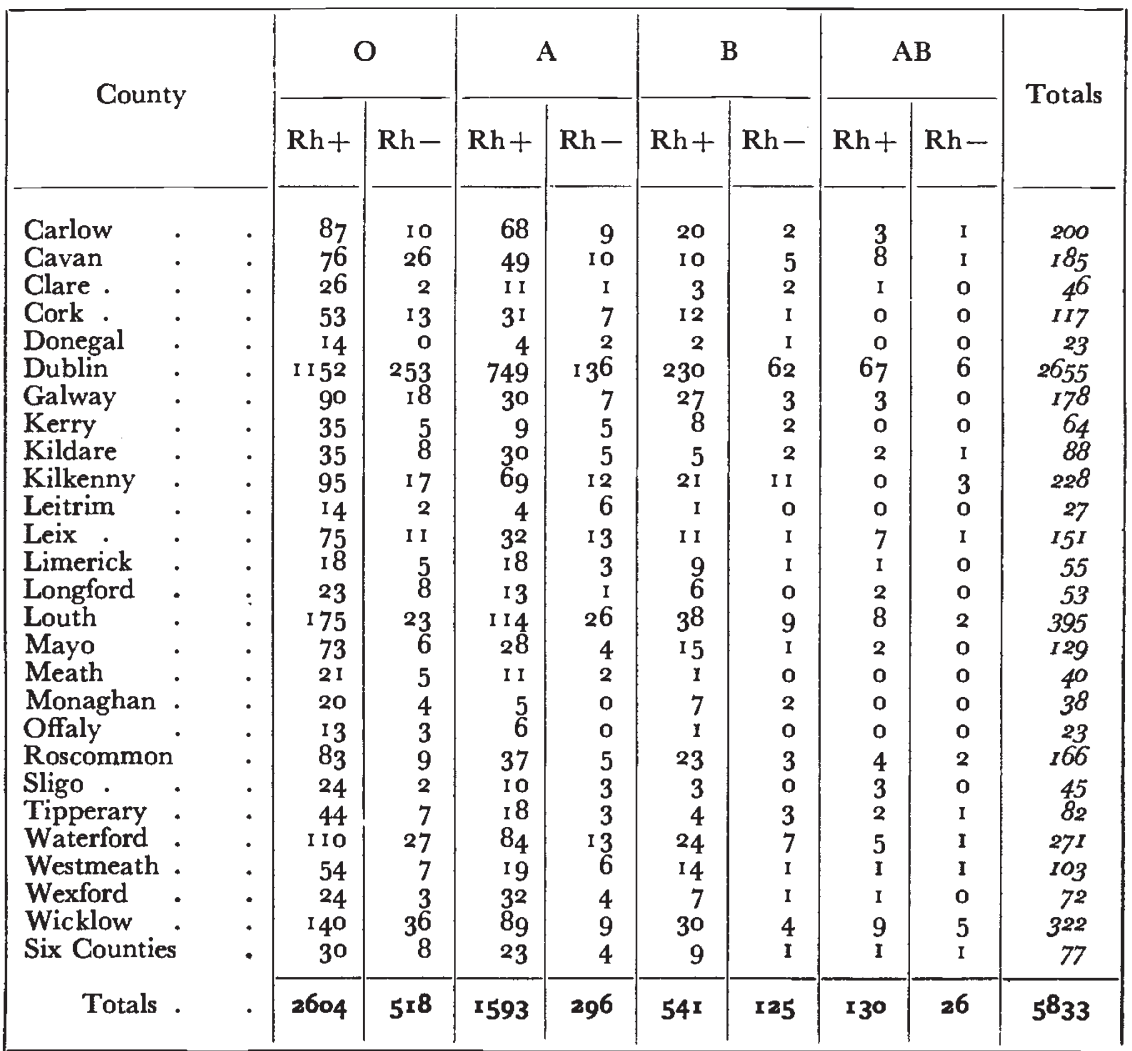

